\title{
A study of alkali-activated concrete mixes with ground granulated blast furnace slag
}

\author{
Mavroulidou M.* and Martynková R. \\ London South Bank University, 103 Borough Road, London SE1 OAA, UK \\ Received: 27/05/2017, Accepted: 24/01/2018, Available online: 26/04/2018 \\ *to whom all correspondence should be addressed: e-mail: mavroum@lsbu.ac.uk
}

\begin{abstract}
The paper presents a laboratory study of concrete mixes based on the alkali-activation of an industrial by-product, ground granulated blast furnace slag (GGBS). A number of factors potentially affecting the resulting concrete quality in terms of workability and strengths were investigated (namely activator type, molarity, curing conditions and times). The statistical significance of the effect of these factors was supported by ANOVA. Higher workability and strengths (with lower activator concentrations) were obtained for $\mathrm{KOH}$ containing mixes. Curing at constant moisture and ambient temperature was successful for most alkaline activators and mixes, which showed good concrete strengths at all curing times; when $\mathrm{Na}_{2} \mathrm{SiO}_{3}$ was used in addition to $\mathrm{NaOH}$ or $\mathrm{KOH}$ activators of moderate to high molarity, strengths exceeded those of Ordinary Portland Cement (CEM-I) concrete of a similar water/cement ratio.
\end{abstract}

Keywords: alkali activated cement concrete, ground granulated blast furnace slag, green construction materials, solid waste management

\section{Introduction}

The aim of this research is to produce successful alkaliactivated concrete mixes containing an industrial byproduct, ground granulated blast furnace slag (GGBS), and a variety of alkali activators. Alkali activated (AA) cements (containing no Ordinary Portland Cement (OPC)) used in the production of concrete could be a very effective way of reducing $\mathrm{CO}_{2}$ emissions by up to five to six times (Davidovits, 2013). An additional advantage is that waste materials or industrial by-products can be used in this type of concrete. According to Provis et al., (2015) and GarcíaLodeiro et al., (2013) the alkali-activated cements may be grouped under two main categories with different respective activation models, namely (1) high-calcium $(\mathrm{Ca}+\mathrm{Si})$ and (2) low-calcium ( $\mathrm{Si}+\mathrm{Al}$ ) activation model, based on the nature of the cementitious components $\left(\mathrm{CaO}-\mathrm{SiO}_{2}-\right.$ $\mathrm{Al}_{2} \mathrm{O}_{3}$ system). An example of the former model is the activation of blast furnace slag (with a $\mathrm{CaO}-\mathrm{SiO}_{2}>70 \%$ ) to give a C-(A)-S-H (calcium (alumino-) silicate hydrate) gel as a main reaction product, which is similar to the gel obtained during OPC hydration (except here Al is also present). Similar to OPC this gel contains silicate groups organised in a long linear chain structure of dreierketten type, of the $\mathrm{SiQ}^{2}$ and $\mathrm{SiQ}^{2}(\mathrm{Al})$ species. On the other hand, the second category comprises activation (under more intense conditions of alkalinity and temperature than for category one) of materials rich mainly in aluminium and silicon, e.g. type F fly ash (low in calcium) and metakaolin. As opposed to category one of AA cements, here the main reaction product is $\mathrm{N}-\mathrm{A}-\mathrm{S}-\mathrm{H}$ (alkaline aluminosilicate) gel, a three-dimensional inorganic alkaline polymer that can be regarded as a zeolite precursor, known as geopolymer. The focus of this paper will be the first type of AA cements. The parameters studied in the paper are: (a) the alkali activator type ( $\mathrm{NaOH}$ or $\mathrm{KOH}$, with or without sodium silicate); (b) the alkaline activator concentration; (c) different curing conditions and (d) curing time.

\section{Materials and methods}

The materials used in this study and their chemical composition are shown in Table 1. GGBS, which came from Hanson Regen, is a by-product of steel production, obtained from the slag (in the form of molten liquid) floating on top of iron in the furnace; for the manufacture of GGBS the slag has to be rapidly cooled in large volumes of water to optimise its cementitious properties. The coarse sand size glassy granules thus produced are then dried and ground to a fine powder, known as GGBS.

For a slag to be suitable for alkali activation it needs to have a high vitreous content of $90 \%$ or more, a large specific surface of $400-600 \mathrm{~m}^{2} / \mathrm{kg}$. Both requirements were satisfied as according to information provided by the suppliers, the GGBS had a vitreous content of $98 \%$ and a specific surface of $450-550 \mathrm{~m}^{2} / \mathrm{kg}$. The slag should also be preferably $\mathrm{pH}$-basic and have a high activity, expressed as a modulus of activity or quality coefficient (Garcia-Lodeiro et al., 2013). The higher the modulus of activity or quality coefficient is, the higher the amount of alkaline compounds present in the slag, which leads to better hydraulic (binding) properties required for successful alkali activation. For the GGBS used in this study the quality coefficient $\mathrm{K}_{\mathrm{q}}$ was calculated as (Eqn 1): 


$$
\mathrm{K}_{\mathrm{q}}=\frac{\mathrm{n}(\mathrm{CaO})+\mathrm{n}(\mathrm{MgO})+\mathrm{n}\left(\mathrm{Al}_{2} \mathrm{O}_{3}\right)}{\mathrm{n}\left(\mathrm{SiO}_{2}\right)+\mathrm{n}(\mathrm{MnO})}
$$

where $\mathrm{n}$ is the amount of substance (mol). The GGBS was found to be of moderate activity $\left(K_{q}=1.6-1.9,\right)$ i.e. adequate, as $K_{q}=1.65$. Moreover, it was basic $\left(K_{b}>1\right)$ considering its basicity coefficient $K_{b}$ defined as (Kim et al., 2015):

$$
\mathrm{K}_{\mathrm{b}}=\frac{\mathrm{n}(\mathrm{CaO})+\mathrm{n}(\mathrm{MgO})}{\mathrm{n}\left(\mathrm{SiO}_{2}\right)+\mathrm{n}\left(\mathrm{Al}_{2} \mathrm{O}_{3}\right)}
$$

where, $n$ is the amount of the substance $(\mathrm{mol}), n=m / M, m$ is the mass of GGBS and $M$ is the molar mass of GGBS compounds. Therefore, the GGBS used herein satisfied all above suitability criteria.

\begin{tabular}{|c|c|c|c|c|}
\hline \multicolumn{2}{|c|}{ Chemical composition } & \multirow[t]{2}{*}{ Chemical composition } & \multicolumn{2}{|c|}{ Pellets } \\
\hline & GGBS & & $\mathrm{NaOH}(\%)$ & KOH (\%) \\
\hline $\mathrm{SiO}_{2}$ & 34.68 & $\mathrm{Na}_{2} \mathrm{CO}_{3}$ & $<2$ & $<2$ \\
\hline $\mathrm{Al}_{2} \mathrm{O}_{3}$ & 14.16 & $\mathrm{Cl}$ & & \\
\hline $\mathrm{CaO}$ & 38.74 & $\mathrm{Ca}$ & $<0.01$ & $<0.005$ \\
\hline $\mathrm{MgO}$ & 7.74 & $\mathrm{Cu}$ & $<0.002$ & $<0.002$ \\
\hline $\mathrm{Fe}_{2} \mathrm{O}_{3}$ & 0.05 & $\mathrm{Fe}$ & $<0.002$ & $<0.002$ \\
\hline $\mathrm{Na}_{2} \mathrm{O}$ & 0.46 & $\mathrm{~Pb}$ & $<0.002$ & $<0.002$ \\
\hline $\mathrm{K}_{2} \mathrm{O}$ & 0.55 & $\mathrm{Mg}$ & $<0.01$ & $<0.002$ \\
\hline $\mathrm{SO}_{3}$ & 0.21 & $\mathrm{Na}$ & & $<1$ \\
\hline $\mathrm{P}_{2} \mathrm{O}_{5}$ & & $\mathrm{~K}$ & $<2$ & \\
\hline $\mathrm{TiO}_{2}$ & & $\mathrm{Zn}$ & $<0.05$ & $<0.005$ \\
\hline $\mathrm{SrO}$ & & $\mathrm{S}$ & $<0.02$ & $<0.01$ \\
\hline $\mathrm{MnO}$ & & $\mathrm{P}$ & $<0.005$ & $<0.02$ \\
\hline $\mathrm{BaO}$ & & $\mathrm{Si}$ & $<0.05$ & $<0.02$ \\
\hline $\mathrm{Li}_{2} \mathrm{O}$ & & & & \\
\hline
\end{tabular}

Table 1. Chemical composition of the materials used based on suppliers' information

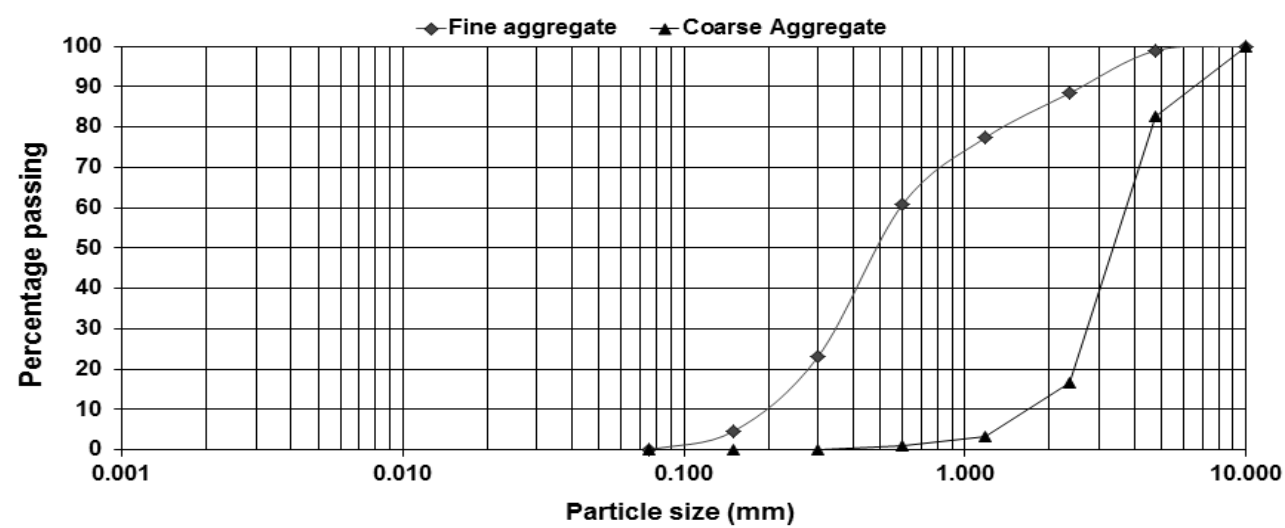

Figure 1. Particle size distribution of the aggregates used in this study

The Thames river aggregate used in the concrete mix was supplied by Travis Perkins. The fine aggregate was sand of a maximum size of $5 \mathrm{~mm}$; the coarse aggregate was crushed gravel of a maximum size of $10 \mathrm{~mm}$. The particle size distribution of the aggregates is shown in Figure 1. Alkaline activators used in this study were supplied by Fisher Scientific and consisted in: (a) Sodium hydroxide solution $(\mathrm{NaOH})$; (b) Sodium hydroxide solution $(\mathrm{NaOH})$ mixed with waterglass (i.e. a sodium silicate $\left(\mathrm{Na}_{2} \mathrm{SiO}_{3}\right)$ solution of a modulus $\mathrm{M}=\mathrm{SiO}_{2} / \mathrm{NaO}_{2}=2$ ); (c) Potassium hydroxide solution ( $\mathrm{KOH})$; (d) Potassium hydroxide solution $(\mathrm{KOH})$ mixed with waterglass. Details of the mix design are shown in Table 2 (masses in $\mathrm{kg}$ were determined with a scale of an accuracy of $+/-0.1 \mathrm{~kg}$ ); for the alkali activators the quantity in $(\mathrm{kg})$ refers to the quantity of the solution used. The notation used for the mixes is as follows: The first letter ' $G$ ' refers to the activated pozzolan (GGBS); it is followed (where applicable) by the ratio of waterglass WG to base activator in terms of mass of solution used ( $\mathrm{N}$ or $\mathrm{K}$ standing for $\mathrm{NOH}$ and $\mathrm{KOH}$ respectively), followed by a number showing the molarity of the latter activator. For example, G_1.5WG_1N_1M refers to a GGBS mix with a 1.5:1 ratio of mass of waterglass to $\mathrm{NaOH}(1 \mathrm{M})$; G_1.5WG_1N_10M refers to a GGBS mix with the same waterglass/ $\mathrm{NaOH}$ mass ratio but a $10 \mathrm{M} \mathrm{NaOH}$ solution, whereas G_1WG_1N_1M refers to a GGBS mix with a waterglass $/ \mathrm{NaOH}$ mass ratio of $1: 1$ and a $1 \mathrm{M} \mathrm{NaOH}$ solution. The activators were mixed at least one day before casting and left in plastic bottles closed securely. All dry ingredients (aggregate, sand, binder) were mixed in a concrete mixer for approximately two minutes; water was then added to the mix followed by the alkali activator. All ingredients were then mixed for another four minutes in the concrete mixer to avoid the formation of granules. Slump tests were performed on the fresh concrete mixes according to BS EN 12350-2:2009 (BSI, 
2009a) before casting into $100 \mathrm{~mm}$ cubic moulds in two layers; each layer was compacted using a vibrating table.

Table 2. Details of alkali-activated concrete mix design (per $1 \mathrm{~m}^{3}$ )

\begin{tabular}{|c|c|c|c|c|c|c|c|}
\hline \multirow{3}{*}{ Mix ID } & \multirow{3}{*}{ GGBS (kg) } & \multirow{3}{*}{ River sand (kg) } & \multirow{3}{*}{$\begin{array}{l}\text { Coarse aggregate } \\
(<10 \mathrm{~mm})(\mathrm{kg})\end{array}$} & \multicolumn{3}{|c|}{ Activator } & \multirow{3}{*}{$\begin{array}{c}\text { Added Water } \\
\text { (kg) }\end{array}$} \\
\hline & & & & \multirow{2}{*}{$\begin{array}{l}\text { Waterglass } \\
\mathrm{Na}_{2} \mathrm{SiO}_{3}(\mathrm{~kg})\end{array}$} & \multicolumn{2}{|c|}{ Hydroxide } & \\
\hline & & & & & $\mathrm{NaOH}(\mathrm{kg})$ & KOH (kg) & \\
\hline G_1.5WG_1N_1M & 415 & 784 & 1039 & 71 & 46 & 0 & 136 \\
\hline G_1.5WG_1N_10M & 415 & 784 & 1039 & 71 & 46 & 0 & 136 \\
\hline G_1WG_1N_1M & 415 & 784 & 1039 & 59 & 58 & 0 & 136 \\
\hline G_1WG_1N_6M & 415 & 784 & 1039 & 59 & 58 & 0 & 136 \\
\hline G_1WG_1N_10M & 415 & 784 & 1039 & 59 & 58 & 0 & 136 \\
\hline G_N_1M & 415 & 784 & 1039 & 0 & 117 & 0 & 136 \\
\hline G_N_10M & 415 & 784 & 1039 & 0 & 117 & 0 & 136 \\
\hline G_1.5WG_1K_1M & 415 & 784 & 1039 & 71 & 0 & 46 & 136 \\
\hline G_1.5WG_1K_4M & 415 & 784 & 1039 & 71 & 0 & 46 & 136 \\
\hline G_K_6M & 415 & 784 & 1039 & 0 & 0 & 117 & 136 \\
\hline
\end{tabular}

Successful curing conditions of alkali-activated concretes vary, depending on the activator chosen and source of material. Thus, to investigate the effect of different curing regimes on the strength of the resulting concrete, samples were then subjected to four different curing methods:

- Method 1 (Adam, 2009): curing at room temperature for 24 hours, demoulding of the samples and water-curing for six days at $20{ }^{\circ} \mathrm{C}$, then wrapping these in cling film to cure at room temperature until required for testing

- Method 2: samples were wrapped in multiple layers of cling film immediately after casting; after 24 hours they were demoulded, then wrapped again in cling film until testing.

- Method 3: samples were wrapped in multiple layers of cling film immediately after casting, then put in the oven at $65^{\circ} \mathrm{C}$ for 5.5 hours (Brough and Atkinson, 2002), then left to cool down overnight; subsequently they were demoulded and watercured at $20^{\circ} \mathrm{C}$ until testing.

- Method 4: samples (still in moulds) were wrapped in multiple layers of cling and placed in a temperature and humidity controlled cabinet at $25^{\circ} \mathrm{C}$ and a relative humidity of $95 \%$. After 24 hours, they were demoulded and put back into the cabinet until testing.

Samples of concrete with Ordinary Portland Cement (OPC) of CEM-I type cement were also prepared at a similar water/cement ratio as the liquid/solid ratio of the alkaliactivated mixes shown in Table 2 (also considering the water used in the solutions); they were used as control mixes to compare the performance of the alkali-activated concrete mixes. The CEM-I concrete was cured using methods 1 and 2 only, i.e. the most usual curing methods for OPC concrete.

\section{Experimental results}

\subsection{Workability (slump test)}

Figure 2 shows the results of tested fresh concrete mixes sorted in ascending order of slump value. Most mixes with $\mathrm{NaOH}$ (with the exception of those with very high $\mathrm{NaOH}$ concentrations of $10 \mathrm{M}$ ) and the mix with $\mathrm{KOH}$ gave pumpable concrete slumps (above $75 \mathrm{~mm}$ ).

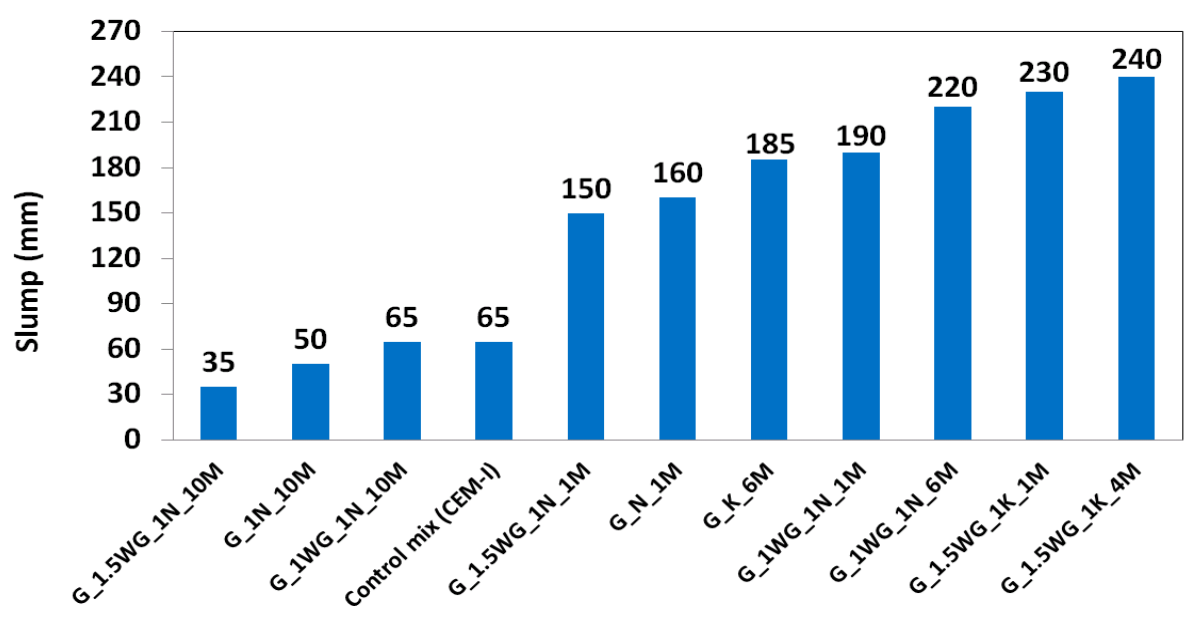

Figure 2. Slump testing results 
For OPC concrete used as a control mix (CEM-I), slump was $65 \mathrm{~mm}$, hence the majority of alkali-activated mixes matched or exceeded this level of workability. Mixes with $\mathrm{KOH}$ and $\mathrm{Na}_{2} \mathrm{SiO}_{3}$ showed collapse rather than true slump but they also hardened very fast; this would be impractical other than for precast concrete; hence further optimisation of these mixes would be needed for more general applications.

\subsection{Cube compressive strength}

\subsubsection{Presentation of results}

The compressive strength of duplicate $100 \mathrm{~mm}$ cube samples was determined according to BS EN 12390-3:2009 (BSI, 2009b) using a Zwick Roell ToniPACT II 2000kN compression test plant and a loading rate of $0.6 \mathrm{MPa}$ per second. Figure 3 represents the highest 28-day curing compressive strengths (i.e. resulting from any one of the curing methods used) of mixes whose 7 day curing strengths were found to be satisfactory (some mixes of Table 2 were excluded from further investigation due to very low early strengths). The results are arranged in descending order of strength magnitude. All mixes showed good compressive strengths, adequate for structural concrete (depending on the design specifications). Specimens with waterglass gave higher strengths than those containing only a base activator $(\mathrm{NaOH}$ or $\mathrm{KOH})$; Moreover, the higher the waterglass content with the same base activator concentration, the higher the strength (see e.g. the $G_{-} 1.5 W G_{-} 1 N_{-} 10 M$ vs the $G_{1} 1 W G_{-} 1 N_{-} 10 M$ mix), which could be due to the enhanced level of alkalinity when waterglass is used (Petermann et al., 2010). In addition comparing the microstructure of $\mathrm{NaOH}$ to $\mathrm{NaOH}$ +waterglass activators a higher amount of crystalline phases in the former mixes were detected (Li et al., 2010) resulting in lower density; this can be linked to the lower strengths observed. Using Scanning Electron Microscopy (SEM) Ben Haha et al., (2012) also detected that $\mathrm{NaOH}$ leads to the formation of dense hydrate rims at the early stages of hydration and to a larger coarse porosity and thus a lower compressive strength compared with waterglass activated samples. Puertas et al, (2018) also observed a lower density and a higher total porosity in $\mathrm{NaOH}$-activated slag concrete mixes compared to WG only -activated slags which they attributed to the presence of silicon in the medium in the latter mixes. Potassium base activator with the same content of waterglass gives a higher strength than the respective mix with sodium base activator of a much higher molarity (see e.g. the G_1.5WG_1K_4M vs. the G_1.5WG_1N_10M mix). Petermann et al., (2010) reason that this is because $\mathrm{K}+$ is more basic, providing a greater extent of dissolution and a higher reactivity of the prime pozzolan (GGBS) and a denser final product / matrix formation, capable of achieving increased compressive strength values. Based on evidence from the activation of low calcium systems (ferronickel slag), Komnitsas et al., (2009) attributed the higher strength of $\mathrm{KOH}$ mixes (compared to that of $\mathrm{NaOH}$ mixes) to the larger size of $\mathrm{K}+$, enabling $\mathrm{KOH}$ to provide more precursors hence the formation of larger silicate oligomers with which $\mathrm{Al}(\mathrm{OH})_{4}$ prefers to bind. In addition, the saturation point of mixes with $\mathrm{KOH}$ would be exceeded if concentrations above $10 \mathrm{M}$ were used, as opposed to $\mathrm{NaOH}$ solutions. The excess $\mathrm{KOH}$ would not react with the raw materials; thus, comparatively lower $\mathrm{KOH}$ concentrations are sufficient to reach high strengths.

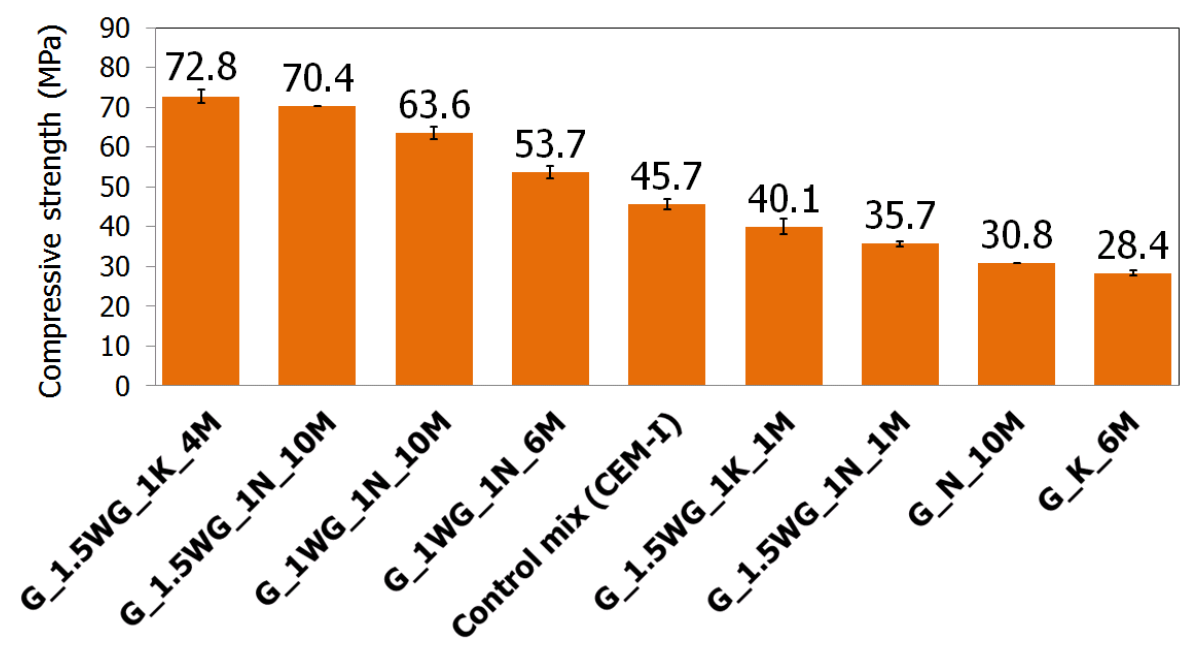

Figure 3. Highest 28-day strengths 




Figure 4. 28-day strengths for four curing methods

Table 3. Strength evolution with curing time for selected mixes

\begin{tabular}{|c|c|c|c|c|c|c|}
\hline Mix & $\begin{array}{l}\text { Curing } \\
\text { Method }\end{array}$ & $\begin{array}{l}\text { Average } 7 \text { day } \\
\text { strength } \\
\text { (MPa) }\end{array}$ & $\begin{array}{l}\text { Average } 28 \text { day } \\
\text { strength } \\
\text { (MPa) }\end{array}$ & $\begin{array}{c}\text { Average } \\
56 \text { day strength } \\
\mathrm{MPa}\end{array}$ & $\begin{array}{c}\text { 7/28 day } \\
\text { strength } \\
\text { ratio* (\%) }\end{array}$ & $\begin{array}{c}28 / 56 \text { day } \\
\text { strength ratio* } \\
\text { (\%) }\end{array}$ \\
\hline \multirow{2}{*}{ Control Mix (CEM-I) } & 1 & $\begin{array}{c}32.7 \\
(\mathrm{SD}=0.7)\end{array}$ & $\begin{array}{c}45.7 \\
(\mathrm{SD}=1.8)\end{array}$ & $\begin{array}{c}47.8 \\
(S D=3)\end{array}$ & 72 & 96 \\
\hline & 2 & $\begin{array}{c}33.6 \\
(S D=0.7)\end{array}$ & $\begin{array}{c}42.8 \\
(S D=0.3)\end{array}$ & $\begin{array}{c}44.1 \\
(\mathrm{SD}=2.7)\end{array}$ & 79 & 97 \\
\hline \multirow{4}{*}{ G_1WG_1N_6M } & 1 & - & - & - & - & - \\
\hline & 2 & $\begin{array}{c}29.6 \\
(\mathrm{SD}=3.8)\end{array}$ & $\begin{array}{c}53.7 \\
(\mathrm{SD}=2.3) \\
\end{array}$ & - & 55 & - \\
\hline & 3 & $\begin{array}{c}43.7 \\
(S D=0.1)\end{array}$ & $\begin{array}{c}44.7 \\
(\mathrm{SD}=0.7)\end{array}$ & - & 98 & - \\
\hline & 4 & $\begin{array}{c}36.9 \\
(\mathrm{SD}=0.2)\end{array}$ & $\begin{array}{c}48.8 \\
(\mathrm{SD}=0.9)\end{array}$ & - & 76 & - \\
\hline \multirow{4}{*}{ G_1.5WG_1N_1M } & 1 & $\begin{array}{c}9.4 \\
(\mathrm{SD}=0.4)\end{array}$ & $\begin{array}{c}20.5 \\
(S D=3)\end{array}$ & - & 46 & - \\
\hline & 2 & $\begin{array}{c}16.7 \\
(\mathrm{SD}=1.2)\end{array}$ & $\begin{array}{c}35.7 \\
(\mathrm{SD}=0.8)\end{array}$ & $\begin{array}{c}38.2 \\
(S D=7)\end{array}$ & 47 & 93 \\
\hline & 3 & - & - & - & - & - \\
\hline & 4 & $\begin{array}{c}19.9 \\
(\mathrm{SD}=0.5)\end{array}$ & $\begin{array}{c}29.7 \\
(S D=2)\end{array}$ & $\begin{array}{c}33.7 \\
(\mathrm{SD}=2.7) \\
\end{array}$ & 67 & 88 \\
\hline \multirow{4}{*}{ G_1.5WG_1K_1M } & 1 & - & - & - & - & - \\
\hline & 2 & $\begin{array}{c}23.1 \\
(S D=4)\end{array}$ & $\begin{array}{c}40.1 \\
(S D=2.7)\end{array}$ & $\begin{array}{c}44.2 \\
(S D=4.5)\end{array}$ & 58 & 91 \\
\hline & 3 & $\begin{array}{c}35.3 \\
(S D=0.4)\end{array}$ & $\begin{array}{c}35.9 \\
(\mathrm{SD}=0.8)\end{array}$ & $\begin{array}{c}37.1 \\
(S D=1.6)\end{array}$ & 98 & 97 \\
\hline & 4 & $\begin{array}{c}23.2 \\
(S D=5.5)\end{array}$ & $\begin{array}{c}31.4 \\
(S D=8.5)\end{array}$ & $\begin{array}{c}35.0 \\
(S D=8)\end{array}$ & 74 & 90 \\
\hline \multirow{4}{*}{ G_1.5WG_1K_4M } & 1 & $\begin{array}{c}31.3 \\
(\mathrm{SD}=0.1)\end{array}$ & $\begin{array}{c}52.1 \\
(\mathrm{SD}=2.4)\end{array}$ & - & 60 & - \\
\hline & 2 & $\begin{array}{c}43.4 \\
(S D=1.4)\end{array}$ & $\begin{array}{c}61.9 \\
(S D=0.1)\end{array}$ & - & 70 & - \\
\hline & 3 & $\begin{array}{c}52.6 \\
(\mathrm{SD}=1.1) \\
\end{array}$ & $\begin{array}{c}55.3 \\
(\mathrm{SD}=2.3) \\
\end{array}$ & - & 95 & - \\
\hline & 4 & $\begin{array}{c}54.6 \\
(\mathrm{SD}=1.2) \\
\end{array}$ & $\begin{array}{c}72.8 \\
(\mathrm{SD}=2.3) \\
\end{array}$ & - & 75 & - \\
\hline \multirow{4}{*}{ G_K_6M } & 1 & $\begin{array}{c}16.5 \\
(S D=0.4)\end{array}$ & $\begin{array}{c}24.1 \\
(\mathrm{SD}=0.9)\end{array}$ & - & 68 & - \\
\hline & 2 & $\begin{array}{c}17.8 \\
(\mathrm{SD}=0.0)\end{array}$ & $\begin{array}{c}28.4 \\
(\mathrm{SD}=0.9)\end{array}$ & - & 63 & - \\
\hline & 3 & $\begin{array}{c}11.8 \\
(S D=0.4)\end{array}$ & $\begin{array}{c}12.5 \\
(\mathrm{SD}=0.4)\end{array}$ & - & 95 & - \\
\hline & 4 & $\begin{array}{c}16.9 \\
(\mathrm{SD}=0.3)\end{array}$ & $\begin{array}{c}24.4 \\
(\mathrm{SD}=0.1)\end{array}$ & - & 69 & - \\
\hline
\end{tabular}


The effect of curing method in conjunction with the results of strength evolution with curing time for different indicative mixes is shown in Figure 4 and Table 3. The table includes the strengths of some selected successful mixes of different types for curing periods longer than 28 days. It can be seen that the CEM-I strengths were exceeded by most alkali-activated cement mixes with added waterglass. From Table 3 and Figure 4 it can also be seen that the trends regarding strength evolution in time according to the different methods are overall consistent across alkaliactivated concrete mixes. Namely, for most mixes the best curing methods in terms of 28-day strength were either 2 or 4 . In general the water curing method (method 1) shows the higher strength gain in time compared to the initial 7 day curing strength values; the method that shows strength evolution trends closer to those of OPC concrete is high humidity curing (method 4). Temperature curing (method 3) may start for most mixes with high strengths at
7 days of curing (in some case the best strengths) but subsequently there is little further strength development in time, so that in terms of 28-day strengths this curing method is the least successful for most mixes. Indeed, for most mixes more than $95 \%$ of the 28 -day curing strength has been achieved already within the first 7 days of curing when using curing method 3 (unlike OPC concrete for which a usual rule of thumb is that approximately $75 \%-80 \%$ of the 28-day strength is achieved within the first 7 days of curing -see also control mix CEM-I in Table 3). Note that mixes with a base activator only (no waterglass) also performed less well under temperature curing (method 3) compared to mixes with the same base activator plus waterglass (see mixes with $\mathrm{KOH}$, i.e. G_1.5WG_1K_1M and G_1.5WG_1K_4M vs. G_K_6M), unlike in Petermann et al., (2010). Mixes with waterglass combined with $\mathrm{NaOH}$ or $\mathrm{KOH}$ gained most strength by 28 days; then the rate of strength increase was slower (as in CEM-I mix).



(a)

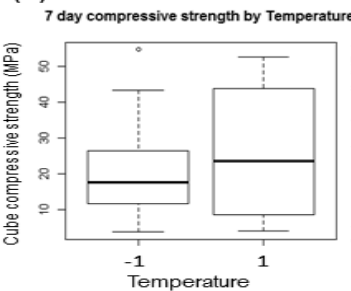

-1


(b)



28 day compressive strength by Temperature
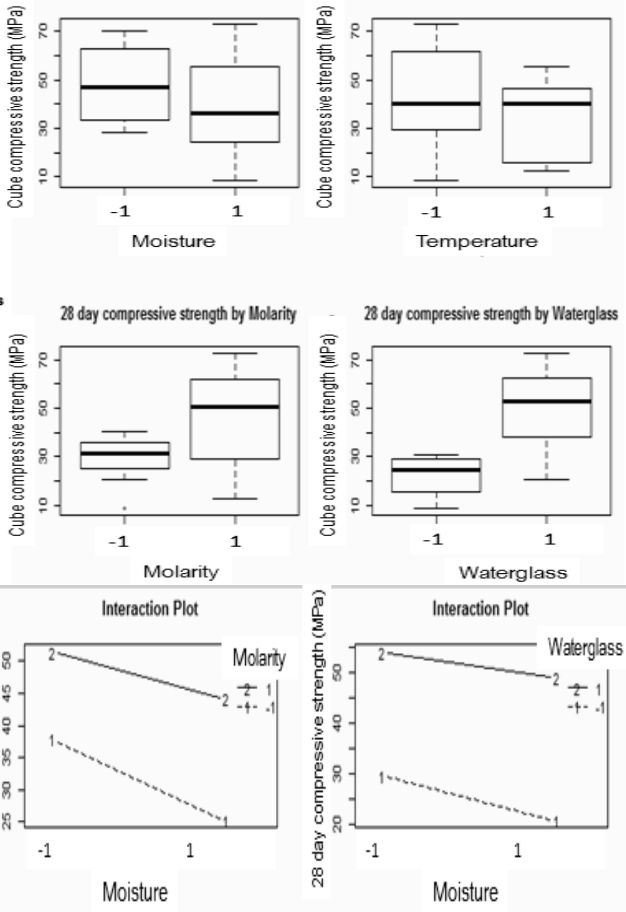

Moisteres

(c)

Figure 5. (a)-(b) Boxplots and (c)-(d) interaction plots for 7 and 28-day strengths 


\subsubsection{Analysis of the results}

To identify the significant factors affecting the compressive strength of the mixes and design future tests accordingly, analyses of the obtained results for 7 and 28 day strengths respectively were performed using software $R$. This was in the form of $n^{k}$ factorial design with the number of factors $k=4$ (in this case "moisture" (Moi), "temperature" (T), "molarity" (Mol) and "waterglass" (WG)) for two respective levels $(n=2)$ of the factors, i.e. -1 (low) and +1 (high) levels. First, descriptive boxplots are shown (Fig. 5 (a)-(b)): the thick horizontal line inside the box represents the median of the dataset; the top line of the box represents the upper quartile ( $25 \%$ of the data are higher than this value); the bottom line of each box represents the lower quartile (25\% of the data are lower than this value); the larger the box, the greater the spread of the data. The top and bottom whiskers represent the distance to the smallest and largest observations that are less than one quartile away from the data contained in the box. Outliers (i.e. observations ranging between 1.0 and 1.5 quartiles away from the limit of the box) are represented by open circles. Based on the boxplots all factors appear to affect the results to some extent; the most visible effects are those of molarity and waterglass for either curing time (based on the considerable differences in the medians according to the level -high or low- of these two factors), followed by moisture for the 28-day strength. Therefore, it is possible that the variation in strength is not due to sample randomization only, and these factors might be able to explain the variation. Variances do not appear to be homogeneous (see the unequal size of the boxes at each level of each factor); this is the case for all factors. Interaction plots (Fig 5(c)-(d)) showed little interaction between factors (lines are mostly parallel) except for a small interaction between molarity and waterglass for both curing times and a pronounced interaction between temperature and molarity at 28 days curing. These observations were consistent with analysis of variance (ANOVA) results, which identified significant factors and binary interactions (see Table 4). Due to the clear nonnormality of the original sample for the 7-day curing results (also confirmed by Shapiro-Wilk test) and the nonhomogeneity of the variances of this dataset (confirmed by the Fligner-Killen test), Kruskal Wallis non-parametric analysis was also performed for 7 days strength; this also showed molarity and waterglass to be significant main factors with a p-value of 0.004409 and 0.002963 respectively (the Kruskal-Wallis null hypothesis is that the mean ranks of the samples from the populations are the same; this was rejected for molarity and waterglass).

Table 4. Relevance order of factors considered (ANOVA results)

\begin{tabular}{|c|c|c|}
\hline Curing time & $\begin{array}{l}\text { Order of factor (significant factors at } 95 \% \text { confidence level } \\
\text { marked by } * \text { ) }\end{array}$ & $\begin{array}{c}\text { Significant binary interactions at } 90 \% \\
\text { confidence level }\end{array}$ \\
\hline 7 days & $\begin{array}{l}\text { Mol* }^{*}\left(p=8.202 \times 10^{-5}\right)>\text { WG }\left(p=8.548 \times 10^{-5}\right)>\mathbf{T}(p=0.20889)>\text { Moi } \\
(p=0.83052)\end{array}$ & Mol:WG $(p=0.08525)$ \\
\hline 28 days & $\begin{array}{l}\text { WG* }\left(p=1.614 \times 10^{-10}\right)>\text { Mol* }^{*}\left(p=2.991 \times 10^{-6}\right)>\text { Moi* }^{*}(p=0.004521) \\
>\mathbf{T}(p=0.053834)\end{array}$ & $\begin{array}{l}\text { T:Mol }(p=0.037068)>\text { Mol:WG } \\
(p=0.097846)\end{array}$ \\
\hline
\end{tabular}

\section{Conclusions}

This study investigated suitable alkali-activated concrete mixes containing GGBS. Most alkaline activators and mixes tested, showed good concrete strengths at all curing times. Curing at constant moisture and ambient temperature was very successful for both alkaline activators and mixes at all curing times. When $\mathrm{Na}_{2} \mathrm{SiO}_{3}$ was used in addition to $\mathrm{NaOH}$ or $\mathrm{KOH}$ activators of moderate to high molarity, strengths exceeded those of OPC concrete of a similar water/cement ratio. Indeed, in addition to base activator molarity, waterglass was found to be the most statistically significant main factor, affecting the strength results. Overall higher strengths and workability were obtained using $\mathrm{KOH}$ at lower concentrations than $\mathrm{NaOH}$, which would be more economical, as the costs of the two activators are similar. However, the rapid hardening of the $\mathrm{KOH}$ mixes with waterglass needs to be addressed with further mix optimisation. In addition, further work with more comprehensive mechanical and durability testing accompanied by microstructural characterisation is ongoing to optimise mixes and address potential issues of this type of concrete.

\section{References}

Adam, A. (2009) Strength and Durability Properties of Alkali Activated Slag and Fly Ash-Based Geopolymer Concrete. Ph. D thesis, Melbourne: RMIT University.

Ben Haha M., Lothenbach B., Le Saout G. and Winnefeld F. (2012), Influence of slag chemistry on the hydration of alkaliactivated blast-furnace slag - Part II: Effect of $\mathrm{Al}_{2} \mathrm{O}_{3}$, Cement and Concrete Research, 42, 74-83.

British Standards Institute (2009a), BS EN 12350-2:2009: Testing fresh concrete. Part 2: Slump test, BSI, London.

British Standards Institute (2009b), BS EN 12390-3:2009: Testing hardened concrete. Part 3: Compressive strength of test specimens, BSI, London.

Brough A.R. and Atkinson A. (2002), Sodium silicate-based alkaliactivated slag mortars. Part I. Strength, hydration and microstructure, Cement Concrete Research, 32, 865-879.

Davidovits J. (2013), Geopolymer cement. A review 2013, Geopolymer Institute. Available from: http://www.geopolymer.org/library/technical-papers/21geopolymer-cement-review-2013. [Accessed $11 / 08 / 13$ ].

García-Lodeiro A., Fernández-Jiménez A. and Palomo E.T. (2013), Alkali-activated based concrete, In: Eco-efficient concrete, Pacheco -Torgal, F. et al.(Eds) Woodhead Publishing, Oxford, 437-487. 
Kim S.W., Jang S.J., Kang D.H., Ahn K.L. and Yun H.D. (2015), Mechanical Properties and Eco-Efficiency of Steel, Fiber Reinforced Alkali-Activated Slag Concrete, Materials, 8, 7309-7321.

Komnitsas K., Zaharaki D. and Perdikatsis V. (2009), Effect of synthesis parameters on the compressive strength of lowcalcium ferronickel slag inorganic polymers, Journal of Hazardous Materials, 161(2), 760-768.

Li C., Sun H. and Li L. (2010), A review: The comparison between alkali-activated slag ( $\mathrm{Si}+\mathrm{Ca})$ and metakaolin ( $\mathrm{Si}+\mathrm{Al})$ cements, Cement and Concrete Research, 40, 1341-1349.

Petermann J.C., Saeed A. and Hammond M.I. (2010), AlkaliActivated Geopolymers: A Literature Review. Report AFRL-RXTY-TR-2010-0097. Air Force Research Laboratory, Florida

Provis J.I., Palomo A. and Shi C. (2015), Advances in understanding alkali-activated materials, Cement and Concrete Research, 78A, 110-125.

Puertas F., Gonzalez-Fonteboa B., Gonzalez-Taboada I., Alonso MM, Torres-Carrasco M., Rojo G. and Martinez-Abella F. (2018), Alkali-activated slag concrete: Fresh and hardened behaviour, Cement and Concrete Composites, 85, 22-31 